\title{
Economic Depreciation in the Property Objects Valuation
}

\author{
Ivanovskiy I.A. ${ }^{a}$ \\ Azmitov R.R. ${ }^{b}$ \\ a b Kazan Federal University, Institute of Management, Economics and Finance, Kazan, 420008, Russia \\ Email: ivanovski@list.ru
}

\section{Doi:10.5901/mjss.2015.v6n1s3p512}

\section{Abstract}

The article reveals the essence of economic depreciation in the property objects valuation. We investigate the methodological aspect of quantitative evaluation of economic depreciation. Two groups of methods traditionally used in economic depreciation valuation of property objects have been examined: (a) based on comparison of similar objects sales, and (b) based on the analysis of income loss. A brief description of these methods is given, identified are the advantages and disadvantages of their use for external economic depreciation value calculation and economic depreciation of property objects. Recommendations have been formulated for practical application of various methods of economic depreciation valuation.

Keywords: valuation, property, economic depreciation, paired sales method, operation loading method

\section{Introduction}

As a result of alterations in the economic relations system and economic reforms in the 90s of the last century the majority of the property complexes belonging to the industrial enterprises in Russia found themselves in a disastrous state. Over time, the fixed assets of the Russian companies were exposed to various factors reducing their technical and operational indexes. The formation of the private property institution and the development of market relations in the real estate sphere started with the adoption of the Law "On Property in the USSR" in 1990. Thus the real cost parameters of property objects became the main factor of market transactions implementing.

The issue of the assets utilization efficiency increase at the Russian enterprises requires new approaches in modern conditions to the property objects valuation and correct calculation of all depreciation types with consideration of heavy moral and physical ageing of facilities, as well as external (economic) ageing, taking into account the changes in the objects' environment. In conditions of crisis the reducing factors associated with the environment are manifested more clearly, which provides for adequate assessment of the external depreciation of property objects.

Determining of opportunities for different methods for economic depreciation of property objects valuation is the aim of this study.

\section{Method}

The theory and practice of valuation activity construes the notion of "depreciation" from two points:

- from technical point of view - it is the degree of the initial consumer properties loss suffered by the object of valuation during its storage or operation;

- from economic point of view - it is the initial or the replacement value loss suffered by the object in relation to the economic impairment or ageing.

Problems in definition of obsolescence for objects of the property are researched in works of many scientists, in particular Constantinescu, M. and M. Francke [1], Jorgenson, D.W. [2].

The appraiser must necessarily explore all types of depreciation applied to the valuated property: physical, functional and external. Particular attention shall be paid to the definition of such property depreciation type as an external (economic) one. Such close attention may be determined both by conceptual features of this depreciation type and conditions of valuation practices in which it is applied.

The procedure of all three depreciation types recording implies a certain sequence: physical depreciation is always considered the first, then the functional one, and only then - the economic depreciation.

Economic depreciation is basically an impairment and restriction of utilization of the property object resulting from 
the economic factors impact generated by the external market environment. The external factors affecting the value of property objects may include: reduction of market demand, the location of the object, transport accessibility, environmental infrastructure, the state of "habitat", legislative and regulatory conditions, etc. For example, the occurrence of a permanent waste disposal site next to an apartment building will lead to the cost of an apartment reduction, whereas the physical and functional characteristics of the premises remain unchanged. Taxation of cars with large engine capacity reduces the demand for them, which leads to reduction of their costs.

Features of definition of economic deterioration are researched in works Mansfield, J.R. and J.A. Pinder [3], Hwang, J.C. [4], Hulten, C.R. and F.C. Wykoff [5], Yakupova, N. and S. Absalyamova [12], Burganova, R.A. and M.F. Salahieva [13].

Economic depreciation caused by the external reasons has a group character and is extended to the entire complex of assets objects intended for example for production of lost demand products. In most cases, economic depreciation is unavoidable, but in some cases it can be eliminated as a result of positive changes in the external market environment [6].

The studies usually distinguish two groups of methods for determination of economic depreciation: (a) methods based on the comparison of similar objects sales under stable or changed external conditions, and (b) methods based on the analysis of the income loss related to the changes in external conditions (Fig. 1).

\begin{tabular}{|c|c|}
\hline \multicolumn{2}{|c|}{ Methods of economic depreciation determining } \\
\hline $\begin{array}{c}\text { Similar objects sales comparison } \\
\text { Under stable or changed external } \\
\text { conditions }\end{array}$ & $\begin{array}{c}\text { Analysis of income losses occurring as } \\
\text { a result of the external conditions } \\
\text { alteration }\end{array}$ \\
\hline$\square$ & $\square$ \\
\hline Paired sales method & $\begin{array}{c}\text { Income losses capitalization method } \\
\text { Economic life period method }\end{array}$ \\
\hline
\end{tabular}

Fig. 1. Methods for determination of economic depreciation

Let us consider in detail the possibility of the indicated methods application.

\section{Result}

Calculation methodology relates the first group to the comparative approach to the property objects valuation, which is based on the principle of substitution, assuming that the buyer will not pay for a particular property more than the possible cost of the similar property object with the same utility. For calculation of economic depreciation using a comparative approach, for example, the method of paired sales, you will need to use information on market prices of similar objects sales. Calculation of the relative index value of economic depreciation $(\mathrm{k})$ is performed using the formula:

$k=\left(C^{1} A-C^{2} A\right) / C^{1} A$,

where $\mathrm{C}^{1} \mathrm{~A}-$ is the value of the object with no signs of external depreciation;

$\mathrm{C}^{2} \mathrm{~A}-$ is the value of the object with the external sign of depreciation.

In practice of valuation activity information on transaction prices is limited, or closed, as the subjects in most cases do not disclose information on the parameters of committed transactions. With a lack of the necessary information on prices of similar objects sale, it is possible to use pricing proposals information making adjustments to the value of discounts information acquired in the bidding process or the amount of growth as a result of the auction. The value of such adjustment is directly influenced by the parameters of a specific property object, market conditions, expected terms of the transaction. Experience shows that for typical objects in a stable market conditions the discount resulting from trading will be $5-10 \%$.

The advantage of this method is the accuracy and clarity of the calculation, its drawback is the complexity of two identical objects finding that may differ only in one parameter.

Calculation methodology relates the second group to the income approach in the property objects valuation. The loss of income capitalization method and the economic life method are the most commonly used ones.

The absolute value of economic depreciation using the loss of income capitalization method is defined as the 
present value of losses (lost profits) related to the economic impairment signs of the property object [7]. Calculation of the absolute value of the external depreciation (D) by the losses capitalization method can be done by the formula:

$D=L P / R \times 100 \%$,

where LP - is the lost profit (losses) related to the external factors impact;

$\mathrm{R}$ - capitalization rate, $\%$.

Capitalization rate is determined by the following formula:

$R=I+I_{r} \pm G$

where I - discount rate, $\%$

Ir - rate of return, \%;

$\mathrm{G}$ - growth (+) or decrease (-) rate of losses in post-forecast period, \%.

Rate of return is taken into account for objects with a deadline of economic life. There are three main methods for the rate of return determining: Ring's, Inwood's and Hoskold's methods.

The Ring's method is applied on the assumption that the principal amount refund will be effected in equal parts. In the Ring model it is assumed that the income flow will decrease annually in a linear mode. The rate of return is calculated as a ratio of $100 \%$ of the asset cost to the remaining economic life period of the facility [8].

The Inwood's method is applied if the amount of capital return is reinvested at the rate of return on investments. The traditional Inwood's model refers to the situation, where the residual lifetime of the object as a whole acts as the forecast period, this ends with the complete loss of the valuated object value [9].

The Hoskold's method is applied in case the income comes regularly; the reimbursement sum is calculated annually and placed on deposit or in other risk-free but low-income instruments [10].

Let us consider the example of economic depreciation calculation using the income loss capitalization method in the valuation of the private brewery building. The brewery is located in a brick building with the total area of 1214 square meters, standard service life of which comprises 100 years.

Chronological age of the valuated object is 47 years.

Tightening of the requirements to the production and sales of alcoholic beverages, a six fold increase in excise duties on beer over the past six years (from 3 rubles per liter in 2009 to 18 rubles per liter in 2014), led to a reduction in production and to the unearned scheduled income.

In 2014, the amount of income losses caused by the tightening of regulatory requirements totaled to 537,802 rubles. Operating income excluding external influences shall amount to 11,251 rubles a year on a per 1 sq.m. of the floor area basis, the actual value of the operating income taking into account external factors has accounted for 10,808 rubles a year.

It is expected that during the three-year forecasted period the absolute value of unearned income will increase; the growth rate of losses in the post-forecast period will be $15.6 \%$. The discount rate is assumed at the level of $12 \%$.

The capitalization rate calculation by the Ring's method is shown in the Table 1.

Table 1. Capitalization rate calculation by the Ring's method

\begin{tabular}{|l|c|}
\hline Index & Value \\
\hline 1. 1. A discount rate, \% & 12 \\
\hline 2. 2. The income loss growth rate in the post-forecast period, \% & 15.6 \\
\hline 3. The standard life of the valuated building, years & 100 \\
\hline 4. Chronological age of the valuated building, years. & 47 \\
\hline 5. The useful life of the building, years (item 3-4) & 53 \\
\hline 6. The rate of return, \% (100\%/item 5) & 1.9 \\
\hline 7. The capitalization coefficient, \% (item1 + 2+6) & 29.5 \\
\hline
\end{tabular}

The absolute value of the valuated building's economic depreciation equals to:

$D=((11,251-10,808) \times 1214) / 0.295=1,823,058$ rubles.

The main difficulty in the practical application of the above studied methods is in determining the zero point of the external depreciation and performance parameters of the object in the absence of external depreciation. Therefore the method basing on the analysis of the operating load is the most widespread in practice for determining of the external depreciation.

The relative value of the external depreciation $(k)$ is determined by the method of operating load by the following formula: 
$k=\left(1-L^{n}\right) \times 100 \%$,

where $L-$ is the operation loading of the asset (group of assets);

$\mathrm{n}$ - braking coefficient or scale factor (usually taken at the level of 0.6-0.7) [11].

The average value of economic depreciation using the method of operation loading can be determined by statistical data about the level of annual production capacity of organizations for the production of certain products. For example, for other enterprises of the brewing industry the maximum loading level reached $81 \%$ in 2007 , with a minimum rate growth of excise duty during the studied period (Fig. 2).

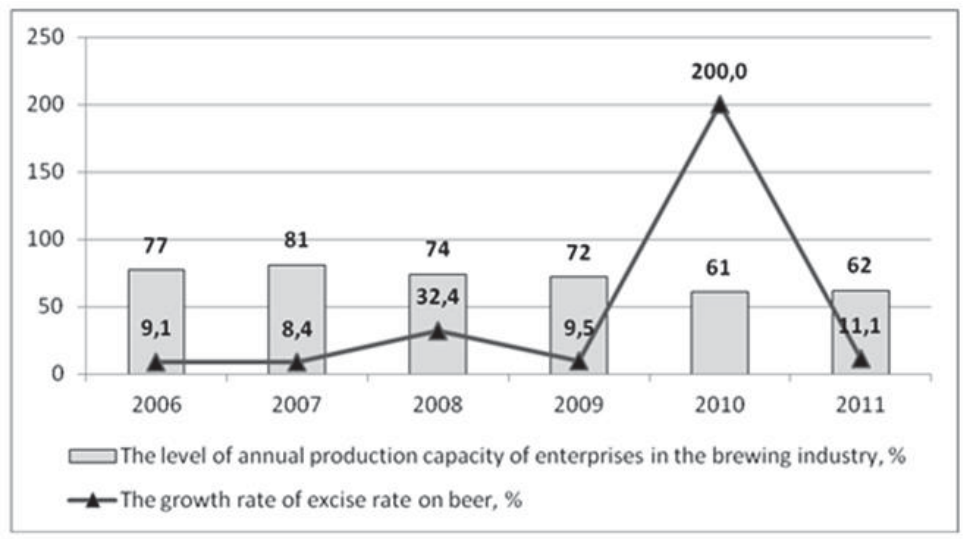

Fig. 2. Dynamics of the annual production capacity level and the rate of the excise duty rate increase for the period of 2006-2011 in the brewing industry

Using the data presented in Figure 2, let us calculate the value of the average economic depreciation in the industry for enterprises of the brewing industry for 6 years:

$\mathrm{k}=\left(1-(62 / 77)^{0.6}\right) \times 100 \%=\left(1-0.8052^{0.6}\right) \times 100 \%=12.2 \%$.

It should be noted that the method of operation loading has significant limitations and can be used in practical calculations only by in-depth analysis of the economic depreciation reasons. Under loading of capacities may be associated not only with the external factors, but also with such as unprofessional management, temporary unfavorable situation, etc. In addition, it would be wrong to take into account in calculation of economic depreciation the under loading of the versatile equipment that can be used in the manufacturing of other products.

Determination of external depreciation is one of the trouble spots of the cost approach to the valuation, as the economic ageing usually affects the entire industry at once, but not each individual object separately. In such circumstances it becomes almost impossible to determine what percentage of the cost is losing one or another particular object under the influence of a general decline in the industry. For example, by valuation of industries, which are in a state of stagnation and regression, the rate of economic depreciation theoretically can reach $100 \%$. But this would mean that the market value of the object is equal to 0 , which in many cases is absurd. Still the object can be sold for some albeit small amount.

There may be no possibility to calculate the external depreciation altogether. At the same time, a situation may occur when the calculated external depreciation, on the contrary, judging from logical reasoning, distort the price estimation of the object. Therefore, the only best solution in this situation is to abandon the calculation of the external depreciation by substantiation of impossibility reasons for determining the external depreciation for an object of valuation.

\section{Conclusion}

Accounting for economic depreciation can reasonably bring the cost of property objects to the real value corresponding to their market prices. At the same time, the recognized methodology for determining of the value of the external depreciation and the inclusion of amendments to the value of the object is still missing. Each of the discussed methods of the external depreciation valuation has both advantages and disadvantages. The choice of method for evaluation remains up to the appraiser. Herewith, by the refusal from economic depreciation calculation it is necessary to give a clear justification for such refusal. In comparative and income approaches the economic depreciation is taken into account indirectly through the relevant industry factors or through the income stream of a particular enterprise. However, by the 
cost approach economic depreciation is subject to a separate valuation.

\section{References}

Constantinescu, M., Francke, M. The historical development of the Swiss rental market - A new price index // Journal of Housing Economics 22 (2), 2013. pp. 135-145.

Jorgenson, D.W. Empirical studies of depreciation // Economic Inquiry 34 (1), 1996. pp. 24-42.

Mansfield, J.R., Pinder, J.A. "Economic" and "functional" obsolescence: Their characteristics and impacts on valuation practice /I Property Management 26 (3), 2008. pp. 191-206.

Hwang, J.C. Forms and rates of economic and physical depreciation by type of assets in Canadian industries // Journal of Economic and Social Measurement 28 (3), 2002. pp. 89-108.

Hulten, C.R., Wykoff, F.C. The estimation of economic depreciation using vintage asset prices. An application of the Box-Cox power transformation // Journal of Econometrics 15 (3), 1981. pp. 367-396.

Mercer, Z.C., Harms, T.W. Business Valuation: An Integrated Theory. 2nd ed. John Wiley \& Sons, Inc., 2007. 288 p.

Fishman, J.E., Pratt, S.P., Griffith, J.C., Wilson, D.K. Guide to Business Valuations. Practitioners Publishing Company (USA), 1994. 410 p.

Hitchner, J.R. Financial Valuation - Applications and Models. 2nd ed. John Wiley \& Sons, Inc., Hoboken, New Jersey, 2006. 1368 p.

Antill, N., Lee, K. Company Valuation Under IFRS: Interpreting and Forecasting Accounts Using International Financial Reporting Standarts. Harriman House Pubishing, 2008. 406 p.

Reilly, R.F., Schweihs, R.P. The Handbook of Advanced Business Valuation. McGraw-Hill, 2006. 512 p.

Copeland, T., Koller, T., Murrin, J. Valuation: Measuring and Managing the Value of Companies. 3rd ed. McKinsey \& Company Inc., 2000. 508 p.

Yakupova, N., Absalyamova, S. Assessment and management of enterprise value // SGEM International Multidisciplinary Scientific Conferences on Social Sciences and Arts. SGEM Conference on Political Sciences Law, Finance Economics \& Tourism. Volume IV, 2014. pp.51-58.

Burganova, R.A., Novak, V.V., Salahieva, M.F. Analysis of Using Capital Asset Pricing Model for Assessing Companies Return /I Mediterranean Journal of Social Sciences. Vol. 5, No. 24, November 2014. Rome, Italy 2014. pp.246-250. 
ISSN 2039-2117 (online) ISSN 2039-9340 (print)
Mediterranean Journal of Social Sciences MCSER Publishing, Rome-Italy
Vol 6 No 1 S3

February 2015 